\title{
Repellant Effect of Urine Insecticides Spray and NPK (15:15:15) Compound Fertilizer Application on the Growth and Yield of watermelon (Citrullu lonatus Thumb)
}

\section{${ }^{* 1}$ AKHIDENO, LO; ${ }^{1}$ SANGOTOYINBO, OA; ${ }^{1}$ YUSUF, AS; ${ }^{1}$ BAKPOLOR, VR; ${ }^{1}$ AKEMIEN, NN; ${ }^{2}$ ADAAJA, BO}

\author{
${ }^{* 1}$ Federal College of Forest Resources and Management, Fugar, Edo State, Nigerian \\ ${ }^{2}$ Trial Afforestation Research Station, Afaka, Kaduna State, Nigeria \\ *Corresponding Author Email: lawsonakhideno@yahoo.com;Tel: 08060366046
}

\begin{abstract}
A field study conducted to investigate the Repellent effects urine insecticide spray and NPK(15:15:15) compound fertilizer on the growth and yield of watermelon (Citrullus Lonatus Thumb) in forestry Research Institute of Nigeria, (FRIN) experimental plot at Agbede, Etsako West Local Government Area of Edo State. Four regimes of Urine insecticide spray and four rate of NPK compound fertilizer application were factorially combined and laid out in a completely randomized block design (CRBD) with three replication. Urine insecticide spray and fertilizer application did not affect the period of flowering and poddring significantly $(\mathrm{P}>0.05)$. NPK compound fertilizer application significantly $(\mathrm{P}<0.05)$ increase the number and length of main vines, pod number and yield while Vines insecticide spray significantly $(\mathrm{P}<0.05)$ increase the length of the main virus and yield. In the rate of application, 200kg/ha NPK was optimum and this recommended for watermelon cultivation. Twice spray regimes of urine insecticide was recommended for watermelon cultivation
\end{abstract}

\section{DOI: https://dx.doi.org/10.4314/jasem.v25i4.9}

Copyright: Copyright $@ 2021$ Akhideno et al. This is an open access article distributed under the Creative Commons Attribution License (CCL), which permits unrestricted use, distribution, and reproduction in any medium, provided the original work is properly cited.

Dates: Received: 14 February 2021; Revised: 26 March 2021; Accepted: 12 April 2021

Keywords: Urine, NPK, growth, Yield, Watermelon

Watermelon (Citrillu Lonatus Thumb) belongs to the family cucerbitaceae. It is grown as a vegetable crop for fresh consumption of the refreshingly juicy and sweet fresh of the nature fruit. Plant Resources of Tropical Africa, (Prota 2008). In many part of the world, watermelon is the most important type of Citrullic Lonatus. Through the demand of watermelon is very high the greatestchallenges to farmers throughout the world and Nigeria in general are the insect pest management (Ladipo et al, 2000).Pest damage caused by insect included damage stem, fruit, leaves and even the entire plants.

Wayne and Wande, (2015) reported that watermelon production is however at risk as substantial losses may occur due to high infestation of insect pest. Okaka et al ; 2008) and Anebunwa (2000) also reported that many factors limit the growth and yield of melon in Nigeria such as poor cultural practices and pest problem. Babu et al ; (2002) also noted that insect, are major setback in watermelon production. That a number of insect including the fruit flies (Dacus spp) chew on various part of watermelon and may transmit diseases pathogens which will destroy or retard the growthand yield of plant. However artificial fertilizer is one of the major recommended cultural practices that increase the yield of watermelon. The response of watermelon to nitrogen fertilizer has been implicated to increase fruit size and seed yield, (Adeniran 1984 Olasantan, 1988 and Sananayake, 2006).Today, the control of insect pest in the field and stored food product has relied heavily in the use of gaseous fumigant and residual contact insecticides. Similarly, the European Union has criticized the use of chemical in the control of insect pest on the field and storage resulting in residual effect to human and environment (Murugen 2006; Fernandez et al, 2007 and Akhideno et al., 2017).

Thus this problem has created the need to find materials that will effectively protect field plant, that are readily available, affordable, less poisonous and less detrimental to the environment. In the light of the above, non - chemical, natural material and method are employed for pest management. Urine has some potential in protecting watermelon plant during the growth and reproductive stages. This can be harnessed in the form of bio - insecticides. The achievement in this direction will increase the demand of watermelon production. This trial is aimed to determined efficiency of urine (both human and animal) in control of insect pest in watermelon. 


\section{MATERIALS AND METHODS}

Study Area: The study was conducted in Forestry Research Institution of Nigeria (FRIN) experimental plot at Agbede Etsako West Local Government Area Edo State. The site has been left fallow for three years before cropping in 2019. The watermelon seed were obtained from ADP office in Auchi while the urine was collected in 12 household in Auchi. The site was manually prepared by clearing with a cutlass and left dried before burning. The debris was packed by hand. The watermelon was sown by hand drilling two seed into $2-4 \mathrm{~cm}$ deep holes at the unset of the rain in May 2019 at the standard spacing of $1 \mathrm{~m}$ by $1 \mathrm{~m}$ which gave an equivalent population density of 10,000 plants/ hectare after supply of missing stands and thinning to one plant by stand.

Each experiment consist of four fertilizer rate and four regimes of urine spray designated $\mathrm{N}_{\mathrm{o}}, \mathrm{N}_{1}, \mathrm{~N}_{2}, \mathrm{~N}_{3}$ and $\mathrm{U}_{0}, \mathrm{U}_{1}, \mathrm{U}_{2}$ and $\mathrm{U}_{3}$, respectively in a $4 \times 4$ factorial scheme fitted with a randomized complete block design with three replications. Each fertilizer treatment was applied at 3WAP by spot application. Urine insecticides were sprayed at the rate of $75 \mathrm{ml}$ at 4, 5 and 6WAP depending on the number of sprays, using a knapsack sprayer. The spray was done in the evening. The urine was collected and then poured into a gallon left for seven to nine days to Ferment. The urine will produce a very pungent scent. The resulting fermented urine can be diluted or used as (insecticide spray). Two hoe weeding were observed at 2 and 5WAP.

Data Collected: Data were collected on the growth characters as from $4 \mathrm{WAP}$ on the number of main vines, length of main vines, number of days to $50 \%$ flowering and podding. At harvest, yield and component of yield were determined on number, diameter and weight per plot. Pod per plot were packed in a jute bag and weighed with a pocket spring balance. Pod diameter were determined from the pod circumference using the conversion formulae; $\mathrm{D}=$ $\mathrm{C} / \mathrm{E}$. where $\mathrm{D}$ is the diameter $\mathrm{C}$ is the circumference and $\mathrm{E}$ is constant taken as 22/7. Data collected were statistically analyzed by analysis of variance while significant means were separated by LSD at 0.05 risk level.

\section{RESULTS AND DISCUSSION}

In table 1 and 2 shows that flowering podding commenced about 4WAP and 6WAP respectively and were neither significantly affected by urine insecticides spray and fertilizer application. Insecticides and fertilization treatment slightly increased length of vegetative growth which lead to the delay onset of the productive phase in the study. This finding is in agreement with Okaka and Remison (1998) who observed that in many arable crops fertilizer have a tendency of increasing vegetative growth phase and many therefore not have direct influence on flowering and podding. The number of main vine produced by each of the watermelon was significantly affected $(\mathrm{P}<0.05)$ by $\mathrm{N}: \mathrm{P}: \mathrm{K} 15: 15: 15$ compound fertilizer application. There was no significant interaction between urine Insecticide spray and fertilizer application as shown in table 3 . It is also revealed that $\mathrm{N}$ : P: K compound fertilizer at any of the application rate significantly increase the number of watermelon main vines.

However the character responded most to $300 \mathrm{~kg} / \mathrm{ha}$ rate of application, while the three application rate produced comparable effect (LSD at 0.05). In table 4, urine insecticide spray and N: P: K 15:15:15 fertilizer application significantly increase the length of watermelon vines. The two factors also significantly interacted. The character to NPK fertilizer application was highest when the rate off application was $300 \mathrm{~kg} / \mathrm{ha}$ which was significantly was higher that $100 \mathrm{~kg} / \mathrm{ha}$ and $200 \mathrm{~kg} / \mathrm{ha}$ rate of application (LSD, 0.05). The response observed was in agreement with the findings of (Anon 1982 and Okaka et al; 2008) reported that for a good canopy spread, a minimum application of $200 \mathrm{~kg} / \mathrm{ha}$ NPK 15:15:15 compound fertilizer should be made to melon plant on the field. Urine insecticides spray significantly increased watermelon vine length as indicated in table 4 that there was a better advantage of three times spray regime than once or twice. The result shows that urine insecticide spray is effective against the folia insect pest of watermelon. This pod number was significantly affected $(\mathrm{P}<0.05)$ by $\mathrm{NPK}$ fertilizer application and urine insecticide spray as shown in table 5. In table $6 \& 7$ shows that pod weight and pod diameter were not significantly affected by the treatment.

Table 1: Repellant Effect

\begin{tabular}{lllllll}
\hline Spray & \multicolumn{7}{c}{ Rate of fertilizer Application (kg/ha) } \\
\hline Regime & 0 & 100 & 200 & 300 & Means & SE+ \\
0 & 35.0 & 36.0 & 38.2 & 38.3 & 36.9 & \\
1 & 34.0 & 35.7 & 36.2 & 39.2 & 36.3 & 1.52 \\
2 & 35.0 & 36.3 & 37.2 & 36.0 & 36.1 & \\
3 & 36.0 & 36.7 & 36.7 & 36.7 & 36.5 & \\
Means & 35.0 & 35.7 & 37.1 & 37.6 & & \\
SE+ & & & 1.53 & & & \\
\hline
\end{tabular}

AKHIDENO, LO; SANGOTOYINBO, OA; YUSUF, AS; BAKPOLOR, VR; AKEMIEN, NN; ADAAJA, BO 
Repellant Effect of Urine Insecticides Spray and NPK.....

Table 2: Repellant Effects of Urine Insecticide Spray and NPK 15:15:15 Fertilizer on the Number of Days to 50\% Podding

\begin{tabular}{lllllll}
\hline Spray & \multicolumn{7}{l}{ Rate of fertilizer Application $(\mathbf{k g} / \mathbf{h a})$} & & \\
\hline Regime & 0 & 100 & 200 & 300 & Means & SE+ \\
0 & 48.2 & 51.0 & 50.2 & 49.0 & 49.6 & \\
1 & 48.2 & 52.0 & 51.6 & 50.0 & 50.5 & 1.26 \\
2 & 48.2 & 52.0 & 51.4 & 50.7 & 50.6 & \\
3 & 48.6 & 52.0 & 50.7 & 49.8 & 50.3 & \\
Means & 48.3 & 51.8 & 51.0 & 49.9 & & \\
SE+ & & & 1.26 & & & \\
\hline
\end{tabular}

Table 3: Repellant Effect of Urine Insecticides Spray and NPK 15:15:15 Fertilizer Application on the Number of Main Vines Produced by Water Melon Plant

\begin{tabular}{lllllll}
\hline Spray & \multicolumn{7}{c}{ Rate of fertilizer Application (kg/ha) } & & \\
\hline Regime & 0 & 100 & 200 & 300 & Means & SE+ \\
0 & 3.2 & 4.2 & 4.1 & 4.4 & 4.0 & \\
1 & 3.1 & 3.9 & 4.1 & 4.3 & 3.9 & 0.39 \\
2 & 3.2 & 4.5 & 4.4 & 4.5 & 4.2 & \\
3 & 3.4 & 3.9 & 3.8 & 4.6 & 3.9 & \\
Means & 3.2 & 4.1 & 4.1 & 4.5 & & \\
SE+ & & & 0.39 & & & \\
\hline
\end{tabular}

Table 4: Repellant effects of Urine Insecticide Spray and NPK 15:15:15 Compound Fertilizer on the Vines length (M) of watermelon

\begin{tabular}{lllllll}
\hline Spray & \multicolumn{7}{l}{ Rate of fertilizer Application (kg/ha) } & & & \\
\hline Regime & 0 & 100 & 200 & 300 & Means & SE+ \\
0 & 1.1 & 2.6 & 1.8 & 3.0 & 2.1 & \\
1 & 1.3 & 2.3 & 2.6 & 3.6 & 2.5 & 0.14 \\
2 & 1.8 & 2.3 & 3.0 & 3.2 & 2.6 & \\
3 & 2.0 & 2.5 & 3.0 & 3.1 & 2.7 & \\
Means & 1.6 & 2.4 & 2.6 & 3.2 & & \\
SE+ & & & 0.14 & & & \\
\hline
\end{tabular}

Table 5: Repellant effects of Urine insecticide spray and NPK 15:15:15 compound fertilizer on Pod Number per plant of watermelon

\begin{tabular}{lllllll} 
Spray & \multicolumn{7}{l}{ Rate of fertilizer Application (kg/ha) } & & \\
\hline Regime & 0 & 100 & 200 & 300 & Means & SE+ \\
0 & 21.0 & 20.0 & 39.2 & 25.7 & 26.5 & \\
1 & 16.2 & 30.0 & 27.1 & 12.1 & 21.4 & 4.03 \\
2 & 16.1 & 29.2 & 12.2 & 10.4 & 17.0 & \\
3 & 12.2 & 18.7 & 25.4 & 26.3 & 20.7 & \\
Means & 16.4 & 24.5 & 26.0 & 18.6 & & \\
SE+ & & & 4.03 & & & \\
\hline
\end{tabular}

Table 6: Repellant Effects of Urine Insecticide Spray and NPK 15:15:15Compound Fertilizer on Pod Diameter (cm) of watermelon.

\begin{tabular}{lllllll}
\hline Spray & \multicolumn{7}{l}{ Rate of fertilizer Application $(\mathbf{k g} / \mathbf{h a})$} & & \\
\hline Regime & 0 & 100 & 200 & 300 & Means & SE+ \\
0 & 15.8 & 18.2 & 17.2 & 13.6 & 16.2 & \\
1 & 16.0 & 16.1 & 16.3 & 16.1 & 16.1 & 6.30 \\
2 & 16.2 & 17.2 & 17.4 & 16.0 & 16.7 & \\
3 & 16.3 & 15.5 & 16.2 & 14.9 & 15.7 & \\
Means & 16.1 & 16.8 & 16.8 & 15.2 & & \\
SE+ & & & 6.30 & & & \\
\hline
\end{tabular}

Table 7: Repellant Effects of Urine Insecticide Spray and NPK 15:15:15 Compound Fertilizer on Pod Weight (kg/ha) of watermelon.

\begin{tabular}{lllllll}
\hline Spray & \multicolumn{7}{l}{ Rate of fertilizer Application $\mathbf{( k g / h a )}$} \\
\hline Regime & 0 & 100 & 200 & 300 & Means & SE+ \\
0 & 0.5 & 0.5 & 0.6 & 0.5 & 0.5 & \\
1 & 0.5 & 0.5 & 0.5 & 0.6 & 0.5 & 6.33 \\
2 & 0.5 & 0.9 & 0.6 & 0.6 & 0.7 & \\
3 & 0.6 & 0.5 & 0.5 & 0.4 & 0.5 & \\
Means & 0.5 & 0.6 & 0.6 & 0.5 & & \\
SE+ & & & 0.03 & & & \\
\hline
\end{tabular}

Pod number increase significantly by the application of $100 \mathrm{~kg} / \mathrm{ha}$ and $200 \mathrm{~kg} / \mathrm{ha} \mathrm{NPK}$, and only slightly increased in $300 \mathrm{~kg} / \mathrm{ha}$ NPK fertilizer. The drastic production was observed when the rate of application is further increase to $300 \mathrm{~kg} / \mathrm{ha}$ NPK fertilization in pod weight and yield of watermelon as shown in table
8. This observation are clear indication of positive infective of fertilization of $100 \mathrm{~kg} / \mathrm{ha}$ and $200 \mathrm{~kg} / \mathrm{ha}$ on pod filling and subsequent yield of watermelon in consonance with the recommendation of $200 \mathrm{~kg} / \mathrm{ha} \mathrm{N}$ : P: K 15:15:15 compound fertilizer (Anon, 1982 an Okaka et al; 2008). 
Table 8: Repellant Effects of Urine Insecticide Spray and NPK 15:15:15 Fertilizer Application on Yield (kg/ha) of watermelon.

\begin{tabular}{lllllll}
\hline Spray & \multicolumn{7}{l}{ Rate of fertilizer } & Application $(\mathbf{k g} / \mathbf{h a})$ & & \\
\hline Regime & 0 & 100 & 200 & 300 & Means & SE+ \\
0 & 73.8 & 120.2 & 700.4 & 95.7 & 247.5 & \\
1 & 95.2 & 351.7 & 432.1 & 120.8 & 250.0 & 42.55 \\
2 & 138.4 & 130.9 & 140.8 & 156.4 & 141.6 & \\
3 & 90.8 & 130.8 & 95.9 & 162.5 & 199.8 & \\
Means & 99.6 & 183.4 & 342.3 & 133.9 & & \\
SE+ & & & 42.55 & & & \\
\hline
\end{tabular}

Urine insecticides spray significantly reduced $(\mathrm{P}<0.05)$ pod number (table 5) while pod diameter (table 6) and pod weight (table 7) were affected ( $\mathrm{P}>0.05)$. These reported is in line with (Okaka 1992 and Okaka et al, 2008) that melon plant exibit some degree of immunity to insect pest attack that insect may retard the growth of melon but the ultimate yield is not affected.The finding in this study shows that watermelon yields can be substantially improved by applying 200kg/ha NPK 15:15:15 compound fertilizer. Urine insecticide spray effectively controlled insect pest of watermelon thereby increasing the vegetative growth in terms of vine spread.This finding is in agreement with the earlier report of (Stoll, 1988, Warbirton and Martin, 1999 and Tancho 2013) that natural materials, non - chemical and method are used for pest management across many regimes, such as Ash, Urine, Soapy water, Neem, Kerosene for crop protection.

\section{REFERENCE}

Adeniran, M. O. (1984): Highlight on Egusi melon (citrullus Lotanus) Improvement in Nigeria. National Institute of Horticultural Research and Training (NIHORT) occasionally paper No 16 NIHORT, Ibadan Nigeria.

Akhideno, LO; Ogboru, RO and Owoeye, EA, (2017): Toxic of Erythrophleum inorense A. cher. (Berk) in stem - Borer insect pest on the growth and reproduction stages of maize plant (zea mays). Greener J. Agric. Sci. 7. 289 - 293.

Anon, (1992): Guide to the Production of Tomatoes, Egusi Melon, Okra and pepper (NIHORT) PRODUCTION GUIDE, Extension and Research liarson and training, National Institute for Horticultural Research and Training (NIHORT), Ibadan Nigeria.

Babu. PG; Reddy,DJ; Jadhav, DR; Chiran jeevi, C and Khan, MAM., (2002): comparative efficacy of selected insecticides against pests of watermelon. Pesticide Res. J. 14(1): 57 - 62.

Okaka, VB (1992): Effect of density, Fertilizer and Intercropping in the Growth and Yield of Melon. A thesis submitted to the post graduate school, Edo State University in partial fulfillment of the requirement for the degree of Master of Science, 1992. Edo State Nigeria.

Okaka, VB; and Remison, SU (1998): Effect of density and fertilization on the performance of melon (Citrullus Lonatus) thumb). Nig. J. Agric. 2(1)49-54.

Murugan, K (2006): Bio pesticides as environmentally soft tool for the management of insect/Mosquito vectors. Int. Symp. On Biocont. And Biotech. Medurai p.34.

Olansantan, FO (1988): The effect of soil temperature and moisture contact on crop Growth and Yield of intercropping maize with melon (cohocyrithis Vulgaris) EXPL. Agric.24: $67-74$.

Okaka, VB; Omoregie, R; Ighalo, SO and Onolemhemhem, PO. (2008): Effects of NPK 15:15:15 compound fertilizer and Sherpa plus insecticides application on the growth and Yield of melon (Citrillus Lonatus thumb). Nig. J. Agric. and Forestry vol. 2(1) $69-77$.

Fernandez, AA, Singh AB and Jaffe, R (2007): A literature Reviewer on trace metal and organic compound of Anthro-pogenic origin in the wider Caribbean Region. Mar. Pollut. Bull.54: 1681 691

Plant resources of Tropical Africa 2 (prota) 2008: Vegetables PPs 185 - 192.

Wanye, GG and Wendy - Ann, PI (2015): Sustainable food production practice in the Caribbean PP. 142 -158 .

Anebunwa, FO (2000) : A bio - economic on farm evaluation on the use of sweet potato for complimentary weed control in a Yam/Maize/Egusi/Cassava intercrop in pigeoropea Hedgerous in the rain forest belt of Nigeria. Biological Agric. Horticulture 18:95 - 102. 
Ladipo, DO, sarumi, MB; Adebisi, AA; and Vodombe (2000) Egusi production utilization and diversity in Nigeria. Agronomy in Nigeria. In: Akoroda, M.O (Editor), Agronomy Re - union Day. A book on theory and practice of Agronomy. University of Ibadan, Nigeria.

Stoll, G (1988): Natural crop protection in the tropics, Germany: Verlay Josef Margraf publishers.
Tancho, A (2003): Natural Farming: principles, concepts and Appropriate Techniques in the Tropic. Thailand: Trio Advertising and media co Ltd.

Warburton, H; and Martin, A; (1999): Local peoples Knowledge in Natural Resources Research, Chatham UK: Natural Resource institute.

Sananayake, SGJN, (2006): Indigenous Knowledge as a key to sustainable Development .J. Agric sci. 2 no $187-94$ 